\title{
The first Stylogaster Macquart, 1835 (Diptera: Conopidae) fossil, from Oligo-Miocene Dominican amber, and some phylogenetic and biogeographic considerations
}

\author{
L. S. G. Rocha ${ }^{1,2, *}$, T. O. Burt ${ }^{3,4}$, C. A. de Mello-Patiu ${ }^{5,6}$, and J. H. Skevington ${ }^{3,4}$ \\ ${ }^{1}$ Graduate Program in Biological Sciences - Zoology, Museu Nacional, Universidade Federal do Rio de Janeiro, \\ Rio de Janeiro, RJ, Brazil \\ ${ }^{2}$ Instituto Federal de Educação, Ciência e Tecnologia do Rio de Janeiro, Campus Nilópolis, Nilópolis, RJ, Brazil \\ ${ }^{3}$ Canadian National Collection of Insects, Arachnids and Nematodes, Agriculture and Agri-Food Canada, Ottawa, \\ ON, Canada \\ ${ }^{4}$ Department of Biology, Carleton University, Ottawa, ON, Canada \\ ${ }^{5}$ Department of Entomology, Museu Nacional, Universidade Federal do Rio de Janeiro, Rio de Janeiro, RJ, Brazil \\ ${ }^{6}$ Research fellow of Conselho Nacional de Desenvolvimento Científico e Tecnológico (CNPq), Brazil \\ * now at: Department of Entomology, Museu Nacional, Universidade Federal do Rio de Janeiro, Rio de Janeiro, RJ, Brazil
}

Correspondence to: L. S. G. Rocha (leonardo.rocha@ifrj.edu.br)

Received: 5 April 2015 - Revised: 14 May 2015 - Accepted: 18 May 2015 - Published: 29 June 2015

\begin{abstract}
Stylogaster Macquart, 1835 has been unknown in the fossil record until now, the only fossil conopid genus being Palaeomyopa Meulnier, 1912. Two Stylogaster specimens in amber from the American Museum of Natural History collection were studied and are described here. Both specimens, male and female, belong to a new species, $S$. grimaldii sp. nov., that is probably basal to at least the New World species with a short ocellar triangle. Photos and drawings of the new species are provided. The relationship with other Stylogaster species and ancient distributional patterns are briefly discussed.
\end{abstract}

\section{Introduction}

Conopidae, or thick-headed flies, are an interesting and understudied group of flies with a nearly worldwide distribution. They are only absent from Antarctica and the islands of Pacific. The adults are nectarivorous and the larvae are obligatory parasitoids of other insects. About 800 extant species of conopids in 58 genera are known, and one fossil genus with two species has been recorded from Baltic amber (Stuke, 2005; Gibson and Skevington, 2013).
Stylogaster Macquart, 1835 is a peculiar genus of Conopidae, with 118 valid species described so far, distributed amongst all biogeographic regions except for the Palaearctic (Papavero, 1971; Camras and Parrillo, 1985; Smith and Peterson, 1987; Yang, 1995; Camras and Parrillo, 1996; Stuke, 2006; Rocha and Mello-Patiu, 2009; Schneider, 2010; Rocha and Mello-Patiu, 2012; Stuke, 2012; Pape and Thompson, 2013, Burt et al., 2014). The genus (thus the subfamily) can be diagnosed by the following characters: a pronounced facial keel, elongated prementum and labella, medial ommatidia larger than all other conopid genera, females with an elongated tube-like terminalia, formed by the segments VI, VII and VIII and dart-like eggs with a hard and scaled chorion and barb-shaped spines (Kotrba, 1997). Stylogaster are parasitoids like all other Conopidae but unlike the others, which are mostly parasitoids of Hymenoptera, Stylogaster's preferred hosts are cockroaches (Blattaria) and grasshoppers and their relatives (orthopteroids). Records of oviposition on calyptrate flies have been described from Africa, but no evidence of development in dipteran hosts has been found (Rettenmeyer, 1961; Couri and Pont, 2006; Couri and Barros, 2010, Couri et al., 2013). In the New World and Africa, many species are associated with army and driver ants, (Hymenoptera: Formicidae: Ecitoninae), with Stylogaster attack- 
ing in the insects that run from the swarms, but not the ants themselves (Lopes, 1937; Smith and Peterson, 1987; Skevington et al., 2010).

Recent phylogenetic analyses give many alternative phylogenetic hypotheses for Stylogaster: one as the sister group of all other conopids, or as sister of the Lauxaniidae, depending on the method of analysis (Gibson et al., 2012; Gibson and Skevington, 2013) or even a paraphyletic Conopidae, inside the Sciomyzoidea, with Stylogaster separated from the other conopids (Wiegmann et al., 2011). The age of Stylogaster has not been proposed before, as the only known fossil conopid genus, Palaeomyopa Meulnier, 1912 is not closely related to Stylogaster (Hennig, 1966; Gibson and Skevington, 2013). The short mouthparts with palps and widely open cell $R_{4+5}$ are putative plesiomorphic characters of Palaeomy$o p a$, while the presence of facial foveae and pad-like extensions of sternite 5 of the female are shared with the nonstylogastrine conopids. Evolutionary studies of Conopidae are important because this family is hypothesized to be the sister taxon to all other schizophoran Diptera (Gibson et al., 2010), thus providing insights into the evolution of diet and parasitoidism amongst the enormous radiation of higher flies. The morphology of the mouthparts and female terminalia suggests that ancestral conopids were nectarivorous and parasitoids (Hennig, 1966), and must have evolved after the appearance of the flowering plants. It remains unclear which hosts are plesiomorphic: orthopteroids or hymenopterans, or another group entirely, unknown to date. The estimated divergence from molecular data between schizophoran and non-schizophoran Diptera is Upper Cretaceous (Santonian age), ca. 84.5 Mya (Bertone and Wiegmann, 2009), although there were no conopids in their analysis. A posterior analysis (Wiegmann et al., 2011), including conopids, found that the Schizophora date from the K-T boundary, ca. 66 Mya. The oldest schizophoran fossil is a Cretaceous (ca. 70 Mya, Maastrichtian age) puparium from Alberta, Canada, Cretophormia fowleri McAlpine, 1970, and its family relationships are uncertain. Except for this, all other fossil Schizophora are Cenozoic (ca. 66 Mya) and very common in Baltic amber, although occurring in younger amber (Grimaldi and Cumming, 1999; Grimaldi and Engel, 2005).

The early-middle Miocene amber-bearing sediments in the Dominican Republic are associated with lignitic material and were formed in a great variety of depositional environments, from coastal to deep marine. The age of the amberbearing sediments is estimated to be from Oligo-Miocene boundary (23 Mya) to middle Miocene (14 Mya) (IturraldeVinent, 2001). The exact formation of origin for the fossil is not provided on the specimen label, but its age corresponds to the amber-bearing sediments cited by IturraldeVinent (2001). This author suggests that those sediments were likely formed from debris produced from active uplift of a highland terrestrial or near-shore area.

This paper aims to describe the first known Stylogaster fossils, compare them with the other conopid fossils, and dis- cuss the systematic and biogeographic relevance of this new species.

\section{Material and methods}

The examined specimens are from the American Museum of Natural History (AMNH) collection.

They were observed with a Leica M80 stereomicroscope and then described. Photographs were taken using a Canon EOS 50D camera with a Canon MP-E $65 \mathrm{~mm} \mathrm{f} / 2.81-5 \mathrm{x}$ Macro Lens and a Canon Speedlite 430EX II flash. The camera was attached to a StackShot (Cognisys Inc.) computerized rail, which was used to take a series of images of the specimen. These images were then montaged with Zerene Stacker version 1.04 (Zerene Systems LLC) to produce one image. The montaged images were edited with Adobe Photoshop. The dorsum was illustrated by tilting the specimen under various lighting conditions to assess, capture and clearly display all the characters necessary for diagnosis. The terminology used here follows McAlpine (1981) and Cumming and Wood (2009), except when contradicted by Gibson et al. (2012), who are then followed.

\section{Results}

\section{Stylogaster grimaldii sp. nov.} (Figures 1-6)

Holotype: Dominican Republic amber, Oligo-Miocene, AMNH specimen no. DR-15-411, 1 male; Paratype: Dominican Republic amber, Oligo-Miocene, AMNH specimen (No DR no. given), 1.5 females.

Type locality: Dominican Republic.

Type stratum: Unknown.

Etymology: Named after Dr. David Grimaldi, who has built an impressive collection of amber for study at the American Museum of Natural History. He obtained the specimens and brought them to our attention.

\section{Male}

Diagnosis: Pedicel and postpedicel subequal in size; ocellar triangle short and pointed; mid basitarsus more than twice as long as the remaining tarsomeres; hind trochanter and femur with long black setae ventrally; tergite 1 with white setae laterally; tergite 5 longer than the others; sternite 5 sclerotized.

Description: Head: Frons yellow, fronto-orbital plate as wide as the scape (Figs. 1a, 2a); gena and facial ca- 

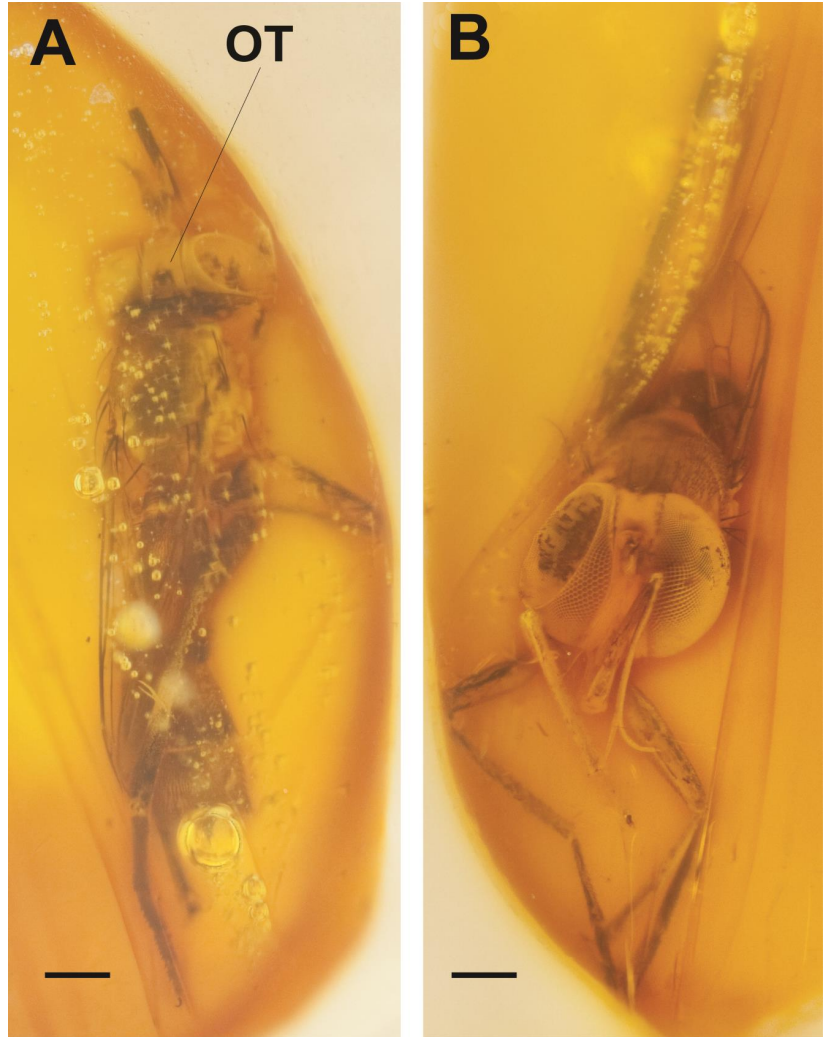

Figure 1. (a) Photo of male Stylogaster grimaldii sp. n., dorsal view. OT, ocellar triangle. (b) Photo of male Stylogaster grimaldii sp. n., frontal view. Scale bar $=1 \mathrm{~mm}$.

rina yellow, seeming to be covered by microtomentum; prementum black at the middle and yellow at tips, basal sheath of prementum clearly visible; ocellar triangle brown and rounded, not reaching middle of the frons, ocellar tubercle prominent (Figs. 1a, 2a); antennae entirely yellow, some setulae dorsally on anterior margin of scape; pedicel and postpedicel subequal in size; arista brown, its third segment enlarged at the base; head setae, per side, are 2 frontal, 6 orbital, 1 ocellar, 1 vertical and 2 occipital, all black (Fig. 2b); occiput and gena covered by white setulae; ommatidia on medial side of the compound eyes slightly enlarged (Fig. 1b).

Thorax: Postpronotal lobe yellow, scutum light brown, supraalar and posterior regions lighter; katepimeron and katepisternum of the same colour as scutum, other pleural sclerites yellow; notopleuron with strongly demarked suture, scutellum pointing upwards; proepisternal setae white, all other black; setae on each side are 1 proepisternal, 1 postpronotal, 2 notopleural, 2 anepimeral, 2 supraalar, 2 dorsocentral, 2 postalar and 1 scutellar (Fig. 2a-b); fore and mid legs yellow; fore and mid coxae with long white setae apically, mid femur with a row of sparse black setae ventrally; fore and mid tibiae coated with white setulae, which are longer apically; fore basitarsus coated with white

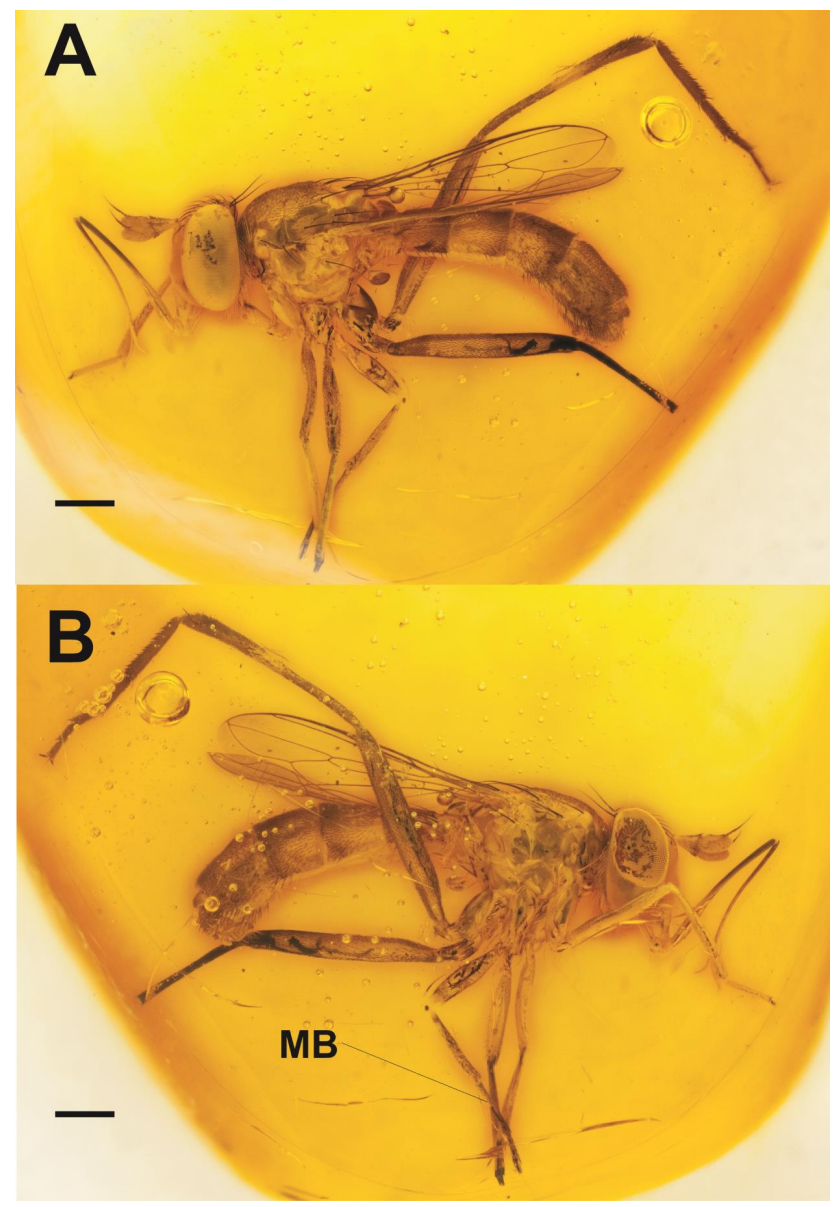

Figure 2. (a) Photo of male Stylogaster grimaldii sp. n., left lateral view. (b) Photo of male Stylogaster grimaldii sp. n., right lateral view. MbT, mesobasitarsus. Scale bar $=1 \mathrm{~mm}$.

setulae; mid basitarsus more than 2-fold longer than the other tarsomeres (Fig. 5); hind coxae light brown, with long black setae apically, seeming to be covered with microtomentum; hind trochanters with black setulae ventrally; hind femur light brown in the tips and yellow in the middle, with moderately long black setae ventrally at the base (Fig. 5); hind tibiae brown with white preapical markings, and dense setulae at the apex; halter rounded, with the lateral half of the knob brown and the medial yellow; wing with one basal seta, costal setulae small; basal radial cell curved apically, $M_{1+2}$ vein slightly curved, forming a petiole with $R_{4+5}$ (Fig. 2b).

Abdomen: Abdominal tergites yellow with light brown posterodorsal markings (Fig. 2b); tergites 2, 3 and 4 subequal in size, tergite 5 slightly larger than the others; tergite 1 with only white setae on the sides, covering all the lateral, tergite 2 with a transversal series of 6 setae, 2 black and 4 white; white setulae present in the anterior ventral margin of tergites 3, 4 and 5; long black setae in the ventral margins of all tergites except tergite 1 ; sternites totally membranous, 


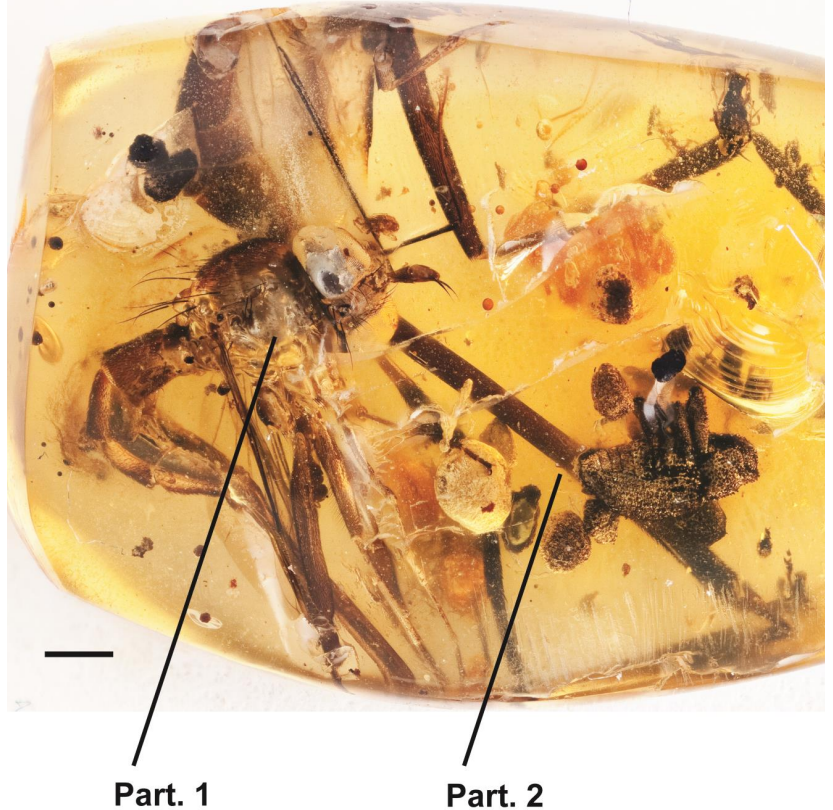

Figure 3. Photo of 1.5 female Stylogaster grimaldii sp. n. right lateral view. Partial specimen 1 is intact except for the tip of terminalia, while all that remains of Partial specimen 2 is the abdomen with the terminalia intact. Part. 1, 2. Partial specimen 1, 2. Scale bar $=1 \mathrm{~mm}$.

but with visible limits.

Terminalia: Mainly yellow; sternite 5 sclerotized, with 2 transversal sets of black setulae; syntergosternite $7+8$ nearly the same size of the epandrium; cerci smaller than posterior surstyli and apparently without hooked apex; cerci and posterior surstyli with black and white setae (Fig. 2b).

\section{Female}

Description: Same as male, except for modified abdomen and terminalia.

Abdomen: Abdomen twice as long as thorax and head combined. Abdominal tergites brownish-yellow, without clear maculation or markings (Figs. 3, 4); tergites 2, 3 and 4 about equal in size, while tergite 5 slightly larger and longer than others; tergite 6 somewhat constricted posteriorly and shorter than 5, and appearing fused with tergite 7 (Figs. 3, $4,6 a)$; tergite 1 with only white setae on the sides, tergite 2 with a transversal series of 4 long black setae; white setulae absent from the anterior ventral margin of tergites 3, 4 and 6; moderately long (shorter than in male) black setae present in the ventral margins of all tergites except tergite 1; sternites 1-6 totally membranous, but with visible limits.

Terminalia: Mainly dark brown; tergite 7 greatly elongated, cylindrical, slender, tube-like; tergite 8 virtually indistinguishable, but appears fused to 7; tergite 9 indistinguishable but also appears fused; tergites 7-8 with short, regular black setae dorsally, ventrally and laterally; sternites appear

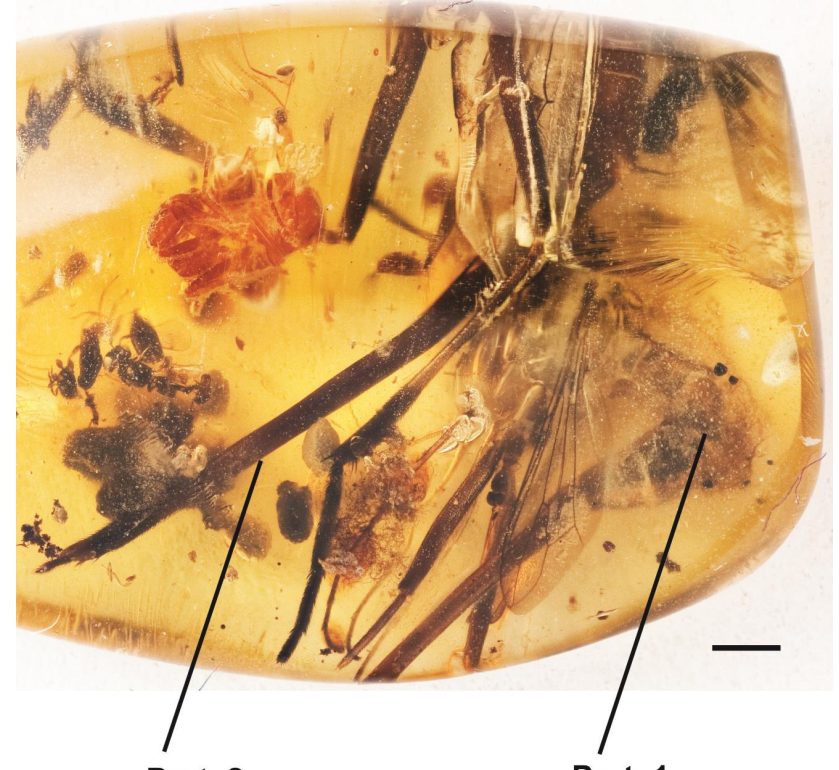

Part. 2

Part. 1

Figure 4. Photo of 1.5 female Stylogaster grimaldii sp. n. left lateral view. Partial specimen 1 is intact except for the tip of terminalia, while all the remains of Partial specimen 2 is the abdomen with the terminalia intact. Part. 1, 2. Partial specimen 1, 2. Scale bar $=1 \mathrm{~mm}$.

fused; lateral lobes appear to protrude from tergite 8 , are short with rounded tips, cercus short with long bushy black setae; hypoproct long (about 10 times as long as length of cercus), and slightly rounded at tip, but arrow-shaped overall, covered in long black setae, bushy (Fig. 6a-b).

Comments: The other two known fossils of Conopidae have been discussed by Hennig (1966), Camras (1994), Stuke (2005) and Gibson and Skevington (2013); both are from Baltic amber. They are not associated directly with extant taxa, but resemble the non-stylogastrine conopids in having mobile female terminalia, pad-like appendices on the sternites and no facial carina protruding. Stylogaster grimaldii is clearly a Stylogaster, having all the characters of the group.

Discussion: The Stylogaster fauna was known only from extant species until now. The discovery of a fossil species from Oligo-Miocene sheds light regarding some questions about the evolutionary history and biogeography of this group.

Recent works on the phylogeny of Conopidae (Gibson et al., 2012; Gibson and Skevington, 2013) place Stylogaster as the sister taxon of the remaining Conopidae. The other fossil conopid group, Palaeomyopa, seems to be more related to the non-stylogastrine conopids than to Stylogaster, although it has not been included in any phylogenetic analysis. Palaeomyopa is known from Baltic amber dated from the early Eocene, 44.1 to 47 Mya (Wolfe et al., 2009), suggest- 


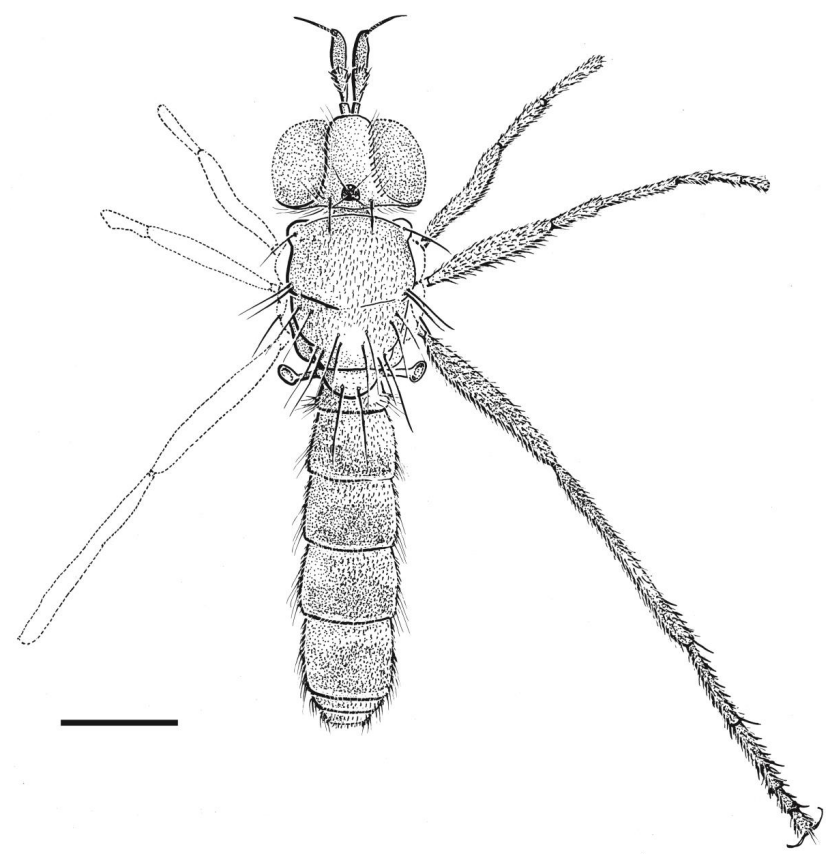

Figure 5. Illustration of male Stylogaster grimaldii sp. n., dorsal view. Scale bar $=1 \mathrm{~mm}$.

ing that the separation between Stylogaster and the Conopidae sensu Hennig (1966) has this minimum age. Stylogaster grimaldii probably dates from the Oligo-Miocene boundary, ca. 23.03 Mya (International Commission on Stratigraphy, 2013; Iturralde-Vinent, 2001).

Stylogaster grimaldii was included in an all-species phylogeny of Stylogaster, which divides the genus into two monophyletic groups, one New World clade and one Old World clade (Rocha et al., unpublished data). The New World group has a short ocellar triangle clade and a long ocellar triangle clade. $S$. grimaldii morphologically resembles the species with a short ocellar triangle, sharing with them many other characters, such as the subequal-sized pedicel and postpedicel and the absence of thick bristles on the epandrium. The hypothesized position of other Stylogaster in this unpublished work is congruent with the molecular and morphological cladogram of Gibson et al. (2012). The hypothesized position of the fossil species, as the sister of all other species with a short ocellar triangle, indicates that the separation between Old/New World and long/short ocellar triangle New World clades is probably older than the Neogene (23.03 Mya). The position of $S$. grimaldii adds little to resolve the conflict concerning the placement of Conopidae within Schizophora (Gibson et al., 2010). Different analytical methods used by Gibson et al. (2010) produced different hypotheses, with Parsimony suggesting that conopids are sister to Schizophora and Bayesian suggesting that Conopidae are sister to Lauxaniidae Macquart. Fossil Lauxaniidae are rare (Evenhuis, 1994) but have been found in Baltic amber (Evenhuis, 1994; Poinar Jr., 1992) and in the Fushun amber of

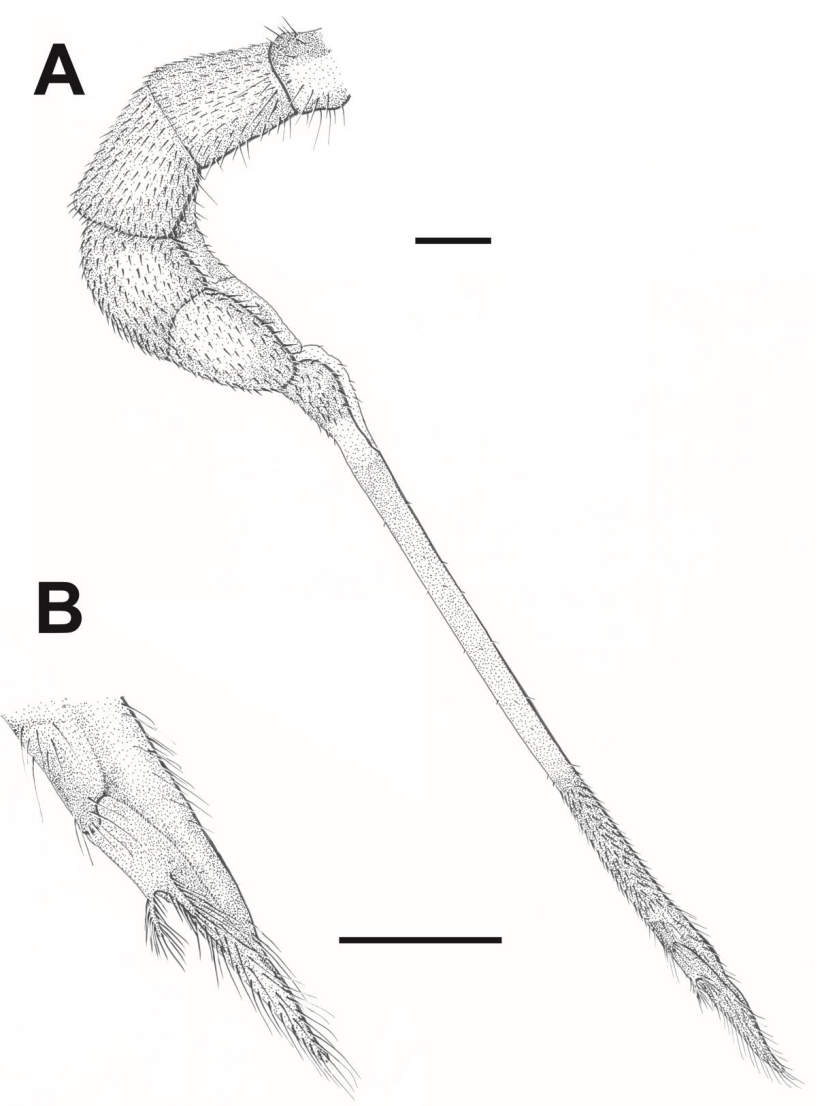

Figure 6. (a) Amalgamated illustration of female abdomen and terminalia of Stylogaster grimaldii sp. n., right lateral view. Scale bar $=1 \mathrm{~mm}$. (b) Illustration of female terminalia of Stylogaster grimaldii sp. n., Partial specimen 2, right lateral, slightly oblique view. Scale bar $=0.5 \mathrm{~mm}$.

China (Szwedo et al., 2013; Hong, 1981). The Fushun amber deposit has been dated to the Paleogene, specifically the Paleocene and early Eocene epochs (50-53 Mya) (Wang et al., 2014). Finding an older conopid fossil (in the 70 Mya range) would add considerable support to the conopid-Schizophora sister hypothesis. Given that the minimum age of conopids (47.9 Mya based on Palaeomyopa) is similar to that of the oldest lauxaniid, both hypotheses remain viable.

Another fossil Stylogaster in Dominican amber, a female, is owned by a private collector in Italy (D. Grimaldi, personal communication, 2014) but could not be obtained at this time. A photo of the specimen can be seen at http://www.terratreasures.com/amber/flagship/ dr5705stylogaster/DR5705stylogaster.htm, but its relationship to $S$. grimaldii is not entirely clear, because the ocellar triangle is not visible. However, the short postpedicel and long female terminalia suggest it is related to $S$. grimaldii. If the identity of this Dominican fossil is confirmed as another new species, then this suggests that there was greater diversity in the Antilles because the only extant species recorded from these islands is $S$. iviei Camras, 2003. The fact that at 
least two lineages are represented by these taxa suggests that the West Indies was an important corridor and has lost much of its fauna through extinction events (Rocha et al., unpublished data). The insights coming from this fossil species illustrate the contribution that fossil taxa can make with respect to conopid phylogenetics.

Author contributions. L. S. G. Rocha analysed the specimens and wrote the descriptions and the main text; T. O. Burt revised the text, especially the conclusions, and made the drawings of the specimens; C. A. de Mello-Patiu and J. H. Skevington revised the text and made major corrections to the primary manuscript.

Acknowledgements. Funding for L. S. G. Rocha came from the Sandwich fellowship programme of CAPES (Coordenação de Aperfeiçoamento de Pessoal de Nível Superior, Brazil, proc. no. 10454-12-8) and FAPERJ - Fundação Carlos Chagas Filho de Amparo à Pesquisa do Estado do Rio de Janeiro, Brazil (proc. no. E-26/110.409/2012). Agriculture and Agri-Food Canada supported L. S. G. Rocha during his work in Ottawa and provide operational funds to J. H. Skevington. We thank David Grimaldi for providing the specimen to us, Jens-Hermann Stuke and Jeff Cumming for guidance and Michelle Locke for taking the stereomicroscopic images of the male specimen. This work is part of the $\mathrm{PhD}$ thesis of L. S. G. Rocha.

Edited by: D. Korn

Reviewed by: J.-H. Stuke and S. Marshall

\section{References}

Bertone, M. A. and Wiegmann, B. M.: True flies (Diptera), in: The Timetree of Life, edited by: Hedges, S. B. and Kumar, S. (Eds.), Oxford University Press, Oxford, United Kingdom, 270-277, 2009.

Burt, T. O., Skevington, J. H., and Rocha, L. S. G.: Revision of Nearctic Stylogaster Macquart (Diptera: Conopidae), Can. Entomol., 146, 1-23, 2014.

Camras, S.: A new subfamily for the fossil conopid fly, Palaeomyopa tertiaria (Diptera: Conopidae), Entomol. News, 105, 175177, 1994.

Camras, S. and Parrillo, P. P.: Review of the New World Stylogaster (Diptera Conopidae), Ann. Entomol. Soc. Am., 78, 111-126, 1985.

Camras, S. and Parrillo, P. P.: New Stylogaster and ranges of Conopidae (Diptera) from the Brazilian and Bolivian Amazonia, Acta Amaz., 25, 221-234, 1996.

Couri, M. S. and Barros, G. P. S.: Diptera hosts of Stylogaster Macquart (Diptera, Conopidae) from Madagascar and South Africa, Rev. Bras. Entomol., 54, 361-366, 2010.

Couri, M. S. and Pont, A. C.: Eggs of Stylogaster Macquart (Diptera: Conopidae) on Madagascan muscids (Diptera: Muscidae), Proc. Calif. Acad. Sci., 57, 473-478, 2006.

Couri, M. S., Pont, A. C., and Kirk-Spriggs, A. H.: New Muscidae (Diptera) hosts of Stylogaster Macquart (Diptera: Conopi- dae) from the Afrotropical Region, Afr. Invertebr., 54, 401-408, 2013.

Cumming, J. M. and Wood, D. M.: Adult morphology and terminology, in: Manual of Central American Diptera, Vol. 1, edited by: Brown, B. V., Borkent, A., Cumming, J. M., Wood, D. M., Woodley, N. E., and Zumbado, M., NRC Research Press, Ottawa, Canada, 9-50, 2009.

Evenhuis, N. L.: Catalogue of the Fossil Flies of the World (INSECTA: DIPTERA), Backhuys Publishers, Leiden, Netherlands, 600 pp., 1994.

Gibson, J. F. and Skevington, J. H.: Phylogeny and taxonomic revision of all genera of Conopidae (Diptera) based on morphological data, Zool. J. Linn. Soc.-Lond., 167, 43-81, 2013.

Gibson, J. F., Skevington, J. H., and Kelso, S.: Placement of Conopidae (Diptera) within Schizophora based on mtDNA and nrDNA gene regions, Mol. Phylogenet. Evol., 56, 91-103, 2010.

Gibson, J. F., Skevington, J. H., and Kelso, S.: A phylogenetic analysis of relationships among genera of Conopidae (Diptera) based on molecular and morphological data, Cladistics, 1, 1-34, 2012.

Grimaldi, D. and Cumming, J. M.: Brachyceran Diptera in Cretaceous ambers and Mesozoic diversification of the Eremoneura, B. Am. Mus. Nat. Hist., 239, 1-124, 1999.

Grimaldi, D. and Engel, M. S.: Evolution of the Insects, Cambridge University Press, New York, United States, xv + 755 pp., 2005.

Hennig, W.: Conopidae im Baltischen Bernstein (Diptera; Cyclorrapha), Stuttg. Beitr. Naturkd., 154, 1-24, 1966.

Hong, Y.: Eocene fossil Diptera Insecta in amber of Fushun coalfield, Geological Publishing House, Beijing, China, 166 pp., 1981.

International Comission on Stratigraphy: International Chronostratigraphic Chart v. 2013/01, http://www.stratigraphy.org/ ICSchart/ChronostratChart2013-01.pdf, last access: 19 June 2013.

Iturralde-Vinent, M. A.: Geology of the Amber-Bearing Deposits of the Greater Antilles, J. Caribb. Sci., 37, 141-167, 2001.

Kotrba, M.: Shoot or stab? Morphological evidence on the unresolved oviposition technique in Stylogaster Macquart (Diptera? Conopidae), including discussion of behavioral observations, Proc. Entomol. Soc. Wash., 99, 614-622, 1997.

Lopes, H. S.: Contribuição ao conhecimento do gênero "Stylogaster" Macquart, 1835 (Dipt.: Conopidae), Arch. Inst. Biol. Veg., 3, 257-293, 1937.

McAlpine, J. F.: Morphology and terminology - adults, in: Manual of Nearctic Diptera. v.1., edited by: McAlpine, J. F., Peterson, B. V., Shewell, G. E., Teskey, H. J., Vockeroth, J. R., and Wood, D. M., Research Branch Agriculture Canada, Ottawa, Canada, 9-63, 1981.

Papavero, N.: Family Conopidae, in: A Catalogue of the Diptera of the Americas South of the United States, edited by: Papavero, N., Museu de Zoologia, Universidade de São Paulo, São Paulo, Brazil, 1-47, 1971.

Pape, T. and Thompson, F. C. (Eds.): Systema Dipterorum, Version 1.5, http://www.diptera.org/, last access: 16 June 2013.

Poinar Jr., G. O.: Life in amber, Stanford University Press, California, United States, 357 pp., 1992.

Rettenmeyer, C. W.: Observations on the biology and taxonomy of flies found over swarm raids of army ants (Diptera: Tachinidae, Conopidae), Univ. Kans. Sci. Bull., 42, 993-1066, 1961. 
Rocha, L. S. G. and Mello-Patiu, C. A.: Revisão das espécies de Stylogaster Macquart do grupo stylata com descrição de uma espécie nova do Brasil (Diptera, Conopidae, Stylogasterinae), Rev. Bras. Entomol., 53, 549-564, 2009.

Rocha, L. S. G. and Mello-Patiu, C. A.: Stylogaster Macquart, 1835 (Diptera: Conopidae) from Northeastern Brazil: New records and two new species, Zootaxa, 3590, 23-36, 2012.

Schneider, M. A.: A taxonomic revision of Australian Conopidae (Insecta: Diptera), Zootaxa, 2581, 1-246, 2010.

Skevington, J. H., Thompson, F. C., and Camras, S.: Conopidae (Thick-Headed Flies), in: Manual of Central American Diptera v.2, edited by: Brown, B. V., Borkent, A., Cumming, J. M., Wood, D. M., Woodley, N. E., and Zumbado, M., NRC Research Press, Ottawa, Canada, 847-855, 2010.

Smith, K. G. V. and Peterson, B. V.: Conopidae, in: Manual of Nearctic Diptera, v.2, McAlpine, J. F., Peterson, B. V., Shewell, G. E., Teskey, H. J., Vockeroth, J. R., and Wood, D. M. (Eds.): Research Branch Agriculture Canada, Ottawa, Canada, 749-756, 1987.

Stuke, J.-H.: Eine neue Gattung der Conopidae aus dem Baltischen Bernstein (Diptera: Conopidae), Beitr. Entomol., 55, 313-318, 2005.

Stuke, J.-H.: Eine neue Art der Gattung Stylogaster Macquart, 1835 aus der Orientalis (Diptera: Conopidae), Entomol. Z., 116, 4042, 2006.

Stuke, J.-H.: A revision of Afrotropical species of Stylogaster Macquart (Diptera: Conopidae), with descriptions of twenty-one new species and an identification key, Afr. Invertebr., 53, 267-354, 2012.
Szwedo, J., Wang, B., and Zhang, H.: The Eocene Fushun amber - known and unknown (Lecture). The International Amber researcher Symposium: Amber. Deposits-Collections-The Market, Gdańsk International Fair Co, Amberif, 2013, 33-37, 2013.

Wang, B., Rust, J., Engel, M. S., Szwedo, J., Dutta, S., Nei, A., Fan, Y., Meng, F., Shi, G., Jarembowski, E. A., Wrappler, T., Stebner, F., Fang, T., Mao, L., Zheng, D., and Zhang, H.: A diverse Paleobiota in early Eocene Fushn amber from China, Curr. Biol., 24, 1606-1610, 2014

Wiegmann, B. M., Trautwein, M. D., Winkler, I. S., Barr, N. B., Kim, J-W., Lambkin, C., Bertone, M. A., Cassel, B. K., Bayless, K. M., Heimberg, A. M., Wheeler, B. M., Peterson, K. J., Pape, T., Sinclair, B. J., Skevington, J. H., Blagoderov, V., Caravas, J., Kutty, S. N., Schmidt-Ott, U., Kampmeier, G. E., Thompson, F. C., Grimaldi, D. A., Beckenbach, A. T., Courtney, G. W., Friederich, M., Meier, R., and Yeates, D. K.: Episodic radiations in the fly tree of life, P. Natl. Acad. Sci. USA, 108, 5690-5695, doi:10.1073/pnas.1012675108, 2011.

Wolfe, A. P., Tappert, R., Muehlenbachs, K., Boudreau, M., McKellar, R. C., Basinger, J. F., and Garrett, A.: A new proposal concerning the botanical origin of Baltic amber, P. Roy. Soc. B-Biol Sci., 276, 3403-3412, 2009.

Yang, C.: The subfamily Stylogasterinae new to China with description of a new species from Guangxi (Diptera: Conopidae), Guangxi Sci., 2, 49-51, 1995. 